Rabbi Eli Kohn

Orot Israel College, Israel

elliottkohn@gmail.com

ORCID: 0000-0001-6576-6961

DOI: http://dx.doi.org/10.12775/BPTh.2021.019
Biblica

et

Patristica

Thoruniensia
14 (2021) 4: 369-381

ISSN (print) 1689-5150

ISSN (online) 2450-7059

\title{
Approaches to the Contradictions in Kohelet*
}

\section{Podejście do sprzeczności w Księdze Koheleta}

\begin{abstract}
The contradictions in the Book of Kohelet have concerned commentators through the ages. This essay offers several approaches to understanding the contradictions in the Book of Kohelet. After a discussion of the weaknesses of each of these approaches I offer a suggestion that shows that the Book has a unified structure and inherent logic. I propose that a philological and literary analysis of the Book, demonstrated through traditional Jewish sources, supports this view. [This article makes use of the author's unpublished Master dissertation, Kohelet a Living Dialogue]
\end{abstract}

Streszczenie. Sprzeczności w Księdze Koheleta od wieków niepokoiły komentatorów. Ten esej przedstawia kilka sposobów zrozumienia sprzeczności w Księdze Koheleta. Po omówieniu słabości każdego z tych podejść wysuwam sugestię, że Księga ma jednolitą strukturę i właściwą jej logikę. Filologiczna i literacka analiza Księgi, oparta na tradycyjnych źródłach żydowskich, potwierdza ten pogląd. [W artykule wykorzystano nieopublikowaną pracę magisterską autora pt. „Kohelet a Living Dialogue”]

Keywords: the Book of Kohelet; the contradictions; the Talmud; the Rabbinical sources; the meaning of life.

Słowa kluczowe: Księga Koheleta; sprzeczności; Talmud; źródła rabiniczne; sens życia.

The traditional approach adopted by the Talmud and later Rabbinical sources is to reconcile the apparently conflicting statements in Kohelet by showing that they use words differently or deal with different topics. For example the Talmud Bavli in Shabbat 30b quotes the verse in Kohelet 8:15: I praised happiness" and interprets it as referring to the happiness that comes from observing command-

* This article makes use of the author's unpublished Master dissertation, Kohelet a Living Dialogue. 
ments, while the verse in Kohelet 2:2: And rejoicing what does this accomplish" writes of pleasure that does not come from keeping the commandments. This approach of harmonizing the supposed contradictions in Kohelet is developed systematically by the Ibn Ezra in his commentary on Kohelet verse 7:3. His basic premise is that: „Even the least of the wise would not write a book and contradict his own words in his book." He continues: „And after the verse itself says of Solomon that there was no man as wise as him we know that his words are not contradictory, and they are fully understood to one who has straight-forward reasoning." He also discusses those who see various authors who wrote Kohelet. He writes "This is not correct because the verse itself says „And more Kohelet was wise” implying he was one man! Furthermore the verse says in 1:12: „I Kohelet was King" showing conclusively that there is one author of the book." The Ibn Ezra reconciles the contradictions in Kohelet by establishing four guiding principles:

(a) Two sentences may in themselves be correct but in differing circumstances. (b) Two sentences one which may be correct and the other the view of a fringe group. (c) Two sentences one which is the rule and one is the exception. (d) Two sentences one that is the view of one group and the other the view of Kohelet himself. We will examine each principle and see how each can be used to answer the contradictions listed earlier.

(a) Kohelet writes in verse 7:9: „For anger resteth in the bosom of fools” whereas in 1: 18 he writes: „For in much wisdom is much vexation.” The Ibn Ezra suggests that Kohelet does not attack the characteristic of anger as such only its manifestations. Therefore the fool is criticized for not being able to control his anger whereas the wise man has self control. Similarly when Kohelet writes in 1:2: „Everything passes” he is referring to people and their actions which are transient whereas in $1: 4:$, The earth always stands" is referring to the creations of G-d which are eternal. This is how Ibn Ezra interprets the apparent contradictions mentioned in Point 1 (Transience versus Stability).

(b) Kohelet writes in verse 7:2: „Better to go to the house of mourning than to go to the house of feasting" which is his true perception of the place of happiness in this world, whereas the verse in 5:17: „Behold I have seen it to be good to eat and to drink and to enjoy pleasure" is the view of the fool and is not to be taken seriously. Similarly the verse in 3:12: "I know there is nothing better for them than to rejoice" is referring to those people in this world who lack wisdom and can only enjoy physical 
pleasures. According to Ibn Ezra then, the contradictions mentioned earlier, in Point 3 under the heading Rejoicing versus Mourning, no longer exist.

(c) When Kohelet writes in 8:13: „But it shall not be well with wicked, neither will he prolong his days" he is giving the state of affairs as it normally is. The verse however in 7:15: „And there is a wicked man that prolongeth his life" is the exemption to the rule, This is how the Ibn Ezra will harmonize the contradictions iii our section on Reward and Punishment

(d) When Kohelet writes in 9:4: „For a living dog is better than a dead lion” he is stating the opinion of others but not his own, whereas in 7:1: „Better the day of deaththan the day one is born" is reflecting Kohelet's own view. This is how the Ibn Ezra reconciles the conflict between Life and Death discussed in Point 2 (Life versus Death).

Mordechai Zer-Kavod in his introduction to Kohelet (p. 26) discusses the Ibn Ezra's interpretation in great detail. Ibn Ezra's approach of reconciling the apparent contradictions in Kohelet by applying his four principles to the conflicting texts is one that appears to me to have merit but has in my opinion substantial flaws as well. While his explanation does provide an answer to the contradictions when applied locally it does not provide for an inherent logical structure for the book as a whole. Even if Ibn Ezra's attempt at harmonization is correct it still does not explain the seemingly haphazard way in which the verses have been put together. Other commentators have adopted different approaches to provide harmony to the book.

Loader, for example, in his book „Polar Structures in the Book of Qohelet" (1979) examines the contradictions in the book and distinguishes in each a "pole" and a "contra-pole". These are balanced by what he calls a "tension." On p. 33, for example, he develops his theory of polar structures by noting the juxtaposition of life and death in the beginning of Kohelet Chapter 7. Life is the "pole” and death is the „contra-pole. Kohelet's purpose is to create a tension between them and to counter the ideas of general hokhma. Death is seen here to be preferable to life. This emphasizes the main theme of the book that all is hevel. Loader emphasizes that the patterns of polarity share a basic similarity. On p. 105 he writes: "Their contents are structured as pole A and pole B where God always works in such a way that a negative, unfavorable tension results (hevel)."

Loader develops his theme by rejecting those approaches that look for a logical structure in the whole book while at the same time not accepting those who 
see Kohelet as a collection of verses strung together with no coherent structure. Loader's approach sees the book composed of what he calls ,separate pericopes." On p. 9 he writes:

We have no logical development of thought reflected in the composition of the book but there are various separate pericopes. These are structured carefully. Without contradicting my first point it can also be said that separate pericopes are compositionally related to each other. The basic idea running through all of them is the conviction of emptiness which purposely begins and ends the book.

I would agree with Fox's (1989) assessment of Loader's work when he writes (p. 20): „I do not always find both „poles” of a contradiction in a single passage. Moreover, even if Loader's conclusion is right, I do not think his analysis of specific passages leads to it. Furthermore, as Wilson cited in Fox (1987) points out, Loader's positive - negative schema often results in forced interpretations. There are those who attempt to see the tensions in the book as a result of additions by another author. For example, James Crenshaw (1987) in his commentary on the book identifies various sections of the book as being added by another writer. In his analysis of the book's structure in the Introduction to his commentary (p. 48), he suggests that the Superscription (1:1), the epilogues and some glosses are not the result of Kohelet's own work but that of someone else. The first epilogue (12:9-11) he suggests was written by a close student of Kohelet's who aims at summarizing the purpose of the book, whereas the second epilogue (12:12-14) was added by a traditional writer who wanted to correct the radical impression created by some of Kohelet's observations.

This attempt by Crenshaw may be challenged on the following grounds. In Crenshaw's view Kohelet's world vision is that of a skeptic whose opinion on theological issues differs greatly from the traditional prospective. To prove this he cites the various examples in the book that refute traditional wisdom. „Hevel havalim says Kohelet” (1:2) shows that Kohelet sees the world as one which has no purpose and direction. „What profit has man for all his labour” (I:3) continues with this theme. Kohelet's logical conclusion according to Crenshaw is: „I said in my heart I will try you with mirth and enjoy pleasure” (2:I). If there is no purpose to life one might as well enjoy it as much as possible. When faced with the Epilogue which has a completely different message of: „The end of the matter all having been heard: fear G-d and keep His commandments for this is the whole man," (12:13) Crenshaw is forced to explain that this is an addition. 
Why is it more logical for Crenshaw to see the beginning of Kohelet as being authentic and the epilogue an addition than to see the opening of the book as an addition and the epilogue as authentic? Furthermore there are verses in the book which seem to support the traditionalist approach and which Crenshaw himself does not view as additions. For example in 8:5 Kohelet writes: „Who keeps the commandment shall know no evil" which is certainly a traditionalist view and in 8:12 he suggests that: „I know that it shall be well with them that fear G-d that fear before Him." Crenshaw himself is aware of the difficulty of categorizing some passages as being authentic and others as being additions and therefore gives another explanation for the contradictions in Kohelet. He writes (p. 49): I believe the tensions of the book represent for the most part the fruit of a lifetime's research. Changing circumstances evoke different responses to conventional wisdom and to one's own former thoughts. Differences in societal concerns also dictate a variety of literary expressions. Kohelet bares his soul in all its twistings and turnings ups and downs and he invites readers to accompany him in pursuit of fresh discovery. But the contradictions suggest more than the result of time's passage! They express the ambiguities of daily existence and the absurdity of human efforts to understand it.

This explanation of the contradictions in the book certainly seems more plausible and logical than the addition theory but suffers one major drawback. It does not explain the fact that Kohelet lacks any discernible progression in thought. The book may indeed „express the ambiguities of daily existence”, but it does so in a very haphazard way. Surely one would expect to see a book of this kind develop its ideas in some form of systematic way? The addition theory has one further problem. If the book was seen to be so offensive in nature to traditional thought that it was felt necessary to add verses to correct the image of the book why did they copy it at all? Surely it would have been more effective to simply suppress the book? As Gordis writes (p. 71):

None of these scholars seeks to explain why the book was deemed worthy of this effort to ,legitimatize" it, when it could so easily been suppressed... it was clear that a given book had been compiled after prophecy had ceased in Israel, or if it contradicted traditional Halachah ... no elaborate effort was undertaken to counteract its heterodox features by glosses and interpolations, as is assumed for Kohelet. Instead, such works were withdrawn by the authorities from public use, by being stored away in the genizah, and thus consigned to oblivion and ultimate destruction. 
If the purpose of the additions was to act as a counterbalance to Kohelet's skepticism then it is questionable whether they achieved their aim. Another approach suggested by the commentators to tackle the problem of contradictions in the book is that of the use of quotations.

Robert Gordis is the main protagonist of this view and in his book, Kohelet - The Man and His World; a Study of Ecclesiastes he devotes a whole chapter to developing his theory. Gordis understands Kohelet to frequently quote other sources for various purposes. He suggests that this characteristic of the book is not unique to Kohelet but can be found in other sections of the Bible and in Talmudic Literature. Gordis (p. 96) defines his use of the term quotations as: Words which do not reflect the personal sentiments of the author of the literary composition in which they are found but have been introduced by the author to convey the standpoint of another person or situation. The use of quotations is, according to Gordis, especially common in Wisdom literature. Teachers of Wisdom would have occasion to quote conventional proverbs for a variety of purposes. These may be cited in order to serve as a text for an ironic or negating comment or they may be brought by the speaker who cites the words and sentiments of his opponents in order to disagree with them. Gordis notes four types of quotations in the book that each have various sub-types. The first type he calls: (p. 99) „The straightforward use of proverbial quotations." These quotations are brought to strengthen an argument and therefore require no expansion or comment because the writer accepts them as true. For example in Kohelet 11:1 he writes: „Send your bread upon the waters so that you may find it again after many days."

According to Gordis Kohelet is here quoting conventional wisdom to suggest that it is wise to diversify one's undertakings. However, as Gordis himself points out, it is difficult to know whether Kohel et is quoting already existing proverbs or composing them himself. A second type of quotation is used by Kohelet to buttress his argument with a proverb, part of which is apposite, while the rest is quoted for the sake of completeness. For example, Kohelet writes in 5:1-2: „Do not hasten to speak nor let yourself be rushed into uttering words before G-d; for $\mathrm{G}-\mathrm{d}$ is in heaven and you are on earth - therefore let your words be few. For "As dreams come with many concerns so the fool speaks with many words." The last sentence is the proverb brought by Kohel et while the rest of the saying is mentioned to complete the idea. The third type of quotation characteristic of Kohelet is the use of proverbial quotations as a text. For example, in Kohelet 7:2 he writes: „Better to go to a house of mourning than to go to a banquet hall." This proverb warns against the immorality of the house of mirth. 
Another example used by Kohelet, emphasizes that love of money does not make for happiness. In Kohelet 5:9 he writes: „He who loves money will never have enough of it, and he who loves wealth will never attain it." The fourth type of quotation which Gordis discusses is the use of contrasting proverbs by Kohelet. Proverbs: frequently contradict one another. For example, Kohelet examines the theme of hard work. He himself has doubts on the subject by quoting the conventional view and following it with another proverb which has an opposite intent. Thus we find in 4:5-6: , The fool folds his hands and thus destroys himself. Better is a handful acquired with ease than two hands full gained through toil and chasing after wind." Often the proverbs contradicting each other are brief ones. For example: „Wisdom is better than strength” but „the poor man's wisdom is despised and his words go unheeded". (9:16) Gordis's approach to the contradictions has much the same effect as the theory of additions. One fundamental problem is the absence of quotation marks in the text. This being so, it is difficult to know whether Kohelet brings a proverb to support his view or to reject it. We do not know therefore Kohelet's relation to the views that the proverbs express. As Fox points out (p. 28): „unless we assume that Kohelet rejects the ideas he is quoting, the quotation hypothesis in itself takes us nowhere."

Of particular interest is Michael Fox's interpretation of the contradictions in Kohelet. In his book, Qohelet And His Contradictions' he attempts to come to an understanding of the contradictions of the book by defining the use of various terms by the author of Kohelet. He stresses that he does not attempt to explain all the contradictions but to give an understanding of the major ones.

Fox's major thesis is that (p. 10):

Kohelet is not primarily concerned with the value of possessions or the worth of human striving but rather with the rationality of existence. This rationality he denies by calling everything hevel. But even in failure, rationality remains an irreducible value, one by which life must be judged.

Fox comes to this conclusion by examining the use of various terms in the book and in particular the use of the word hevel. In Chapter 1 of his book Fox examines the various uses of the word hevel in the Bible and comes to the conclusion that in Kohelet, hevel means absurd. Kohelet sees the world and witnesses phenomena that appear to contradict each other. Kohelet, according to Fox, recognizes these contradictions and uses them for his claim that ,everything is absurd". Fox writes (p. 11): 
Kohelet uses contradictions as the lens through which to view life; it is appropriate, then, that we use his contradictions as the angle of approach to his thought. Exegesis has usually sought to push Kohelet to one side or the other, to show him consistently pious or consistently skeptical and pessimistic. I have tried to be faithful to the uneasy tensions that I see as characterizing Qohelet's attitudes and world view.

In other chapters of his book, Fox highlights areas of tension and contradiction that Kohelet sees exist in the world. For example in Chapter 2, Fox analyses how the word a'mal (toil) is used in the book of Kohelet. On the one hand Kohelet sees that toil is absurd and without any advantage, yet it provides wealth and is a source of pleasure. This contradiction leads Kohelet to praise toil on the one hand while criticizing it on the other. If toil is absurd how can it be good as well? In Chapter 3, Fox examines Kohelet's understanding of wisdom. Here too we find a basic contradiction. On the one hand Kohelet affirms the value of wisdom and knowledge and on the other he seems to deny it. This tension arises out of Kohelet's life experiences and we are left with the question, what can we know and why should we know it? In Chapter 4, Fox deals with Kohelet's understanding of G-d's judgment in the world. Here too we find basic contradictions. Kohelet has been brought up to understand G-d as being merciful and just, and he cannot understand how in life this does not always seem to be the case. Life is unjust but G-d is just. How then, he asks, are we to understand the moral quality of the world? All these topics are dealt with in depth by Fox. His basic conclusion that Kohelet is dealing with the rationality of existence is one that has much worth.

However, I find two major difficulties with Fox's approach. Firstly, like many other commentators we have discussed, Fox does not explain the inner structure and coherent logic of the book. The themes dealt with by Kohelet are fundamental to the meaning of life, but the connection between the themes does not seem to flow one to the other. Fox would counter that Kohelet deals with each theme separately and develops his view on each theme independently as he sees the world. However, I think that there is more structure to the book and between the themes than Fox would have us imagine. Secondly, Fox's conclusion that Kohelet is dealing with the absurdities of life seems somewhat problematic when one considers the reason why Kohelet was included in the works of the Bible. For what purpose did the sages include Kohelet into the canon if it is a work which looks at the contradictions of life and leaves us with more questions than answers? Fox attempts to answer this question when he writes (p. 138): 
The book's conclusion helped its acceptance as sacred scripture, for it „ends with words of Torah" (Bavli Shah. 30b). Since it is the last word in the book, the familiar piety of the conclusion could outweigh the uncomfortable observations of the preceding twelve chapters.

Fox's comment here is questionable. A closer look at the words of the Talmud Bavli in Shabbat 30b leads me to a different conclusion. The Talmud writes:

Rabbi Judah the son of R. Samuel b. Shilath said in Rav's name: The sages wished to hide the Book of Kohelet because its words are self-contradictory; yet why did they not hide it? Because its beginning is religious teaching and its end is religious teaching.

This statement of the Talmud states explicitly that Kohelet was included in the canon because both its beginning and its end included words of religious teaching. The implication is that several verses at the end of Kohelet which emphasize „familiar piety” would not have on their own been enough to dispel the "uncomfortable observations" of the first twelve chapters. It was only because the sages saw that the beginning and the end of the book contained religious teaching that they decided to include it in the canon.

In the following analysis of the first section of the book this essay attempts to show that there is an inner structure and cohesion to the book. The essence of the thesis is that Kohelet is a book that opens a discussion between characters rather than a monologue. This gives the book logical consistency and cohesiveness. Recent theories of literature will enable us to look at the book as a whole through a synchronic reading and help us to understand the „so called” contradictions.

Understanding Kohelet as a dialogue has its source in the words of the Meiri in his introduction to the Book of Mishle. He writes (p. 2):

Kohelet mentions views and one stands confused wondering which one is correct. He thus mentions in a number of places views that contradict fundamental beliefs such as reward and punishment, God's providence in this world. He mentions these views so as to search through knowledge which is the correct path.

This thesis identifies four characters of Kohelet -the builder, the philosopher, the man of pleasure and the God fearing individual. These four characters all attempt to answer the question - what is the meaning of life? Each section or chapter of the book is a speech being made by one of these characters trying to prove that his view of life is correct. Through debate and comment these 
characters finally come to an understanding of the truth. Hence a philological and literary analysis of the speeches of the characters, demonstrated through traditional Jewish sources, supports my view.

A commentary on the whole book to support this thesis goes beyond the scope of this essay. Therefore a short commentary on the beginning of the book where the characters are presented is presented here.

\section{Presentation of the characters of Kohelet}

1:12: I Kohelet have been King over Israel in Jerusalem.

1:13: And I applied my heart to seek and to search out by wisdom concerning all things that are done under heaven; it is a sore task that G-d has given to the sons of men to be exercised therewith.

1:14: I have seen all the works that are under the sun; and, behold, all is hevel and a striving after wind.

1:15: That which is crooked cannot be made straight; And that which is wanting cannot be numbered.

1:16: I spoke with my own heart, saying: ,Lo, I have gotten great wisdom, more also than all that were before me over Jerusalem'; yea, my heart has had great experience of wisdom and knowledge.

1:17: And I applied my heart to know wisdom, and to know madness and folly I perceived that this also was a striving after the wind.

1:18: For in much wisdom is much vexation; And he that mcreases knowledge increases sorrow.

Ch. 2:1: I said in my heart: ,Come now, I will try thee with mirth, and enjoy pleasure'; and, behold, this also was have.

2:2: I said of laughter: It is mad'; and of mirth:, What does it accomplish?'

There is uncertainty about the point at which this section ends. Some commentators like Crenshaw, see the passage ending at 2:26. These commentators suggest that this section describes the life of the King and his successes and disappointments. My suggestion is that the section should end with 2:3 and that we have in this section a presentation of three of the major characters of the book and the problems that each one encounters.

1:13 opens with a statement that the author is searching for the truth and he finds that what is done in the world is evil $\left(\mathrm{ra}^{\prime}\right)$ The use of the word " $r \mathrm{r}^{\prime}$, , in this section is pronounced. Altogether "ra” , and its comparable words are used seven times. In 1:14, he sees that all the works that are done are „Ot roah”. In 1:17, 
he sees wisdom and knowledge as being "ra'yon roah", striving after wind. Despite this pessimistic outlook on life we will see that Kohelet develops his attitude to life through the course of the book, and this opening statement is not necessarily Kohelet's conclusion. What is interesting is the division within this section between three aspects of the life of man.

In 1:14, he writes: „I have seen all the works that are done under the sun and behold all is hevel'. In 1:16, he discusses the importance of wisdom in his life and says: „I have gotten great wisdom, more than all that were before me." In $2: 1$, he says: „come now I will try you with happiness and enjoy pleasure”. What we have here, perhaps, are three aspects of life; work, wisdom and enjoyment. These aspects, we will show, are in fact a prelude to the three characters who are developed by Kohelet in the next few chapters. Labor, corresponds to the ,'Amel" who sees work and the development of the physical world as the purpose of life. Wisdom corresponds to the "Hakham" who is the architect and thinker of how the world looks. Enjoyment corresponds to the „Neheneh”, who feels that having fun and enjoying life is the purpose of living, in this world.

These three figures are presented in this section but each figure has a problem with his own view of life. The builder sees all his works, yet pronounces in 1:15: „That which is crooked cannot be made straight, and that which is wanting cannot be numbered." He sees the world that he has built, but also sees that there are short comings to his work, and that one can never achieve perfection. The wise man sees wisdom as being central to the purpose of life but says in I:18: „For in much wisdom is much vexation: And he that increases knowledge increases sorrow." The possession of wisdom merely serves to reveal more realistically the imperfections of the world order, thereby increasing one's weariness and unhappiness. The more one knows the more the despair because of the reality that the world cannot be perfected. Finally, the search for purpose leads Kohelet to the man of pleasure. Here too, however, there are short comings. Kohelet says: „I said of laughter it is mad; and of mirth what does it accomplish?” The man who drinks and enjoys his physical pleasures may indeed have a good time but this is only transitory. It does not last for long and often a person may feel worse after the enjoyment than before. If this is so, what then is the purpose of physical enjoyment? Work, wisdom and enjoyment have each been presented as a possible answer to the purpose of life.

Kohelet shows that each one of these solutions has an inherent problem and only through debate and dialogue will we be able to expose and find the answer to the question that lies at the heart of the book: What is the purpose of life? 
In summary, this essay has offered several approaches to understanding the contradictions to the book of Kohelet. After a discussion of the weaknesses of each one of the approaches we offered a suggestion that shows that the book has a unified structure and inherent logic. We identified four characters of Kohelet the builder, the philosopher, the man of pleasure and the God fearing individual. These four characters all attempt to answer the question - what is the meaning of life? Each section or chapter of the book is a speech being made by one of these characters trying to prove that his view of life is correct. Through debate and comment these characters finally come to an understanding of the truth. A philological and literary analysis of the speeches of the characters, demonstrated through traditional Jewish sources, supports this view.

\section{Bibliography}

Barton, J. 1984. Reading the Old Testament. London: Darton Longman and Todd. Cohen, A. 1961. The Five Megilloth. (Soncino Books of the Bible). London: Soncino Press. Crenshaw, J.L. 1987. Ecclesiastes „Ecclesiastes Book of” Anchor Bible Dictionary pp. 271280. Philadelphia.

Crenshaw, J.L. 1987. Ecclesiastes - A Commentary. Philadelphia: Westminster Press.

Dell, K.G. 1994. "Ecclesiastes As Wisdom. Consulting Interpreters." Vetus Testamentum XLIV: 301-329.

Fox, M.V. 1989. Qohelet and his Contradictions. Sheffield: Almond Press.

Ginsberg, H.L. 1955. „The Structure and Contents of the Book of Kohelet.” Vetus Testamentum Sup. 3: 138-49.

Ginsberg, H.L. 1961. Kohelet (In Hebrew). Jerusalem: Moriah Publishers.

Gordis, R. 1968. Kohelet The Man and His World. New York: Shocken Press.

Hengel, M. 1974. Judaism and Hellenism. Vol 1: 115-131. Philadelphia: Fortress Press.

Kohn, E. 1996. Kohelet a Living Dialogue. Unpublished Masters thesis University of Cape Town.

Loader, J.A. 1979. Polar Structures in the the Book of Qohelet. Berlin: De Gruyter.

Ogden, G.S. 1987. Kohelet. Sheffield: JSOT Press.

The Jewish Publication Society of America. The Holy Scriptures, Philadelphia, 1955.

Whitley, C.F. 1979. Kohelet His Language and Thought. Berlin: De Gruyter.

Whybray, R.N. 1989. Ecclesiastes. (The New Century Bible Commentary). London: JSOT Press.

Zer-Kavod, M. 1973. Kohelet (In Hebrew). Jerusalem: Mossad Harav Kook.

Zimmerman, F. 1973. The Inner world of Kohelet. New York: Ktav. 


\section{Rabbinic literature bibliography}

Halevi, Rabbi Yehuda. 1972. The Kuzari. Tel Aviv: Dvir Publishers.

Hertz. 1963. The Chumash. London: Soncino Press.

Ibn Ezra. 1959. Mikra ot Gedolot. Tel Aviv: Pardes Publishers.

Meiri. 1968. Commentary on the Book of Mishle. O'tzar Haposkim. Jerusalem: Moriah Publishers

Metzudat David. 1959. Commentary on Kohelet. Mikra ot Gedolot. Tel Aviv: Pardes Publishers.

Midrash Rabah, Kohelet. 1961. Lewin-Epstein, Jerusalem: Mossad Harav Kook.

Rashi. 1959. Commentary on Kohelet. Mikra ot Gedolot. Tel Aviv: Pardes Publishers.

Talmud Eruvin. 1963. Jerusalem: Hatalmud Hameoa'r.

Talmud Shabbat. 1963. Jerusalem: Hatalmud Hameoa'r. 